Fernando Binvignat

\title{
De las pequeñas canciones
}

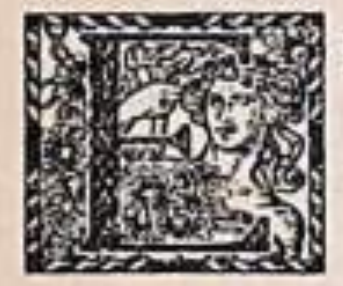

N la mañana de Junio voy transido y solitario caminando junto al mar con tu recuerdo en los brazos.

Junfo al mar que llora y llora su responso cotidiano, en la mañana de Junio voy transido y solitario.

Este cielo gris en mi alma es un hondo desamparo. Yo voy tan triste, tan triste, con tu recuerdo en los brazos.

Tu amor es esta tristeza. este invencible quebranto, que hacen de mi corazón un caliz turbio de llanto.

Tu amor es esta armagura que voy llorando y llorando. 
como el mar en la mañana de Junio, su desamparo.

¡Ay, como un infante llevo tu recuerdo entre los brazos, como un niño enfermo y triste que no consuela mi llantol 